\title{
The Development Trend of Domestic Electronic Schoolbag and Comparative Study of Mainstream Products
}

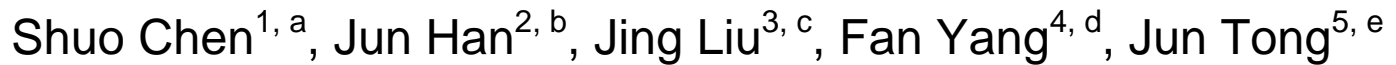 \\ ${ }^{1}$ Department of Educational Technology, Capital Normal University, BeiJing, 100048, China \\ ${ }^{2}$ Department of Educational Technology, Capital Normal University, BeiJing, 100048, China \\ ${ }^{3}$ Department of Educational Technology, Capital Normal University, BeiJing, 100048, China \\ ${ }^{4}$ Department of Educational Technology, Capital Normal University, BeiJing, 100048, China \\ ${ }^{5}$ Department of Educational Technology, Capital Normal University, BeiJing, 100048, China \\ aemail: cskaoyandota@sina.com
}

Keywords: Electronic Schoolbag; Basic Function; Characteristic Function; Development Trend

\begin{abstract}
This paper focuses on the comparison and comment of domestic mainstream brand electronic schoolbag's basic functions and its implementation details, and enumerates and comments on some brand electronic schoolbag's characteristic functions. At the end of this article, the paper introduces the development trend of the domestic electronic schoolbag.
\end{abstract}

\section{Introduction}

With the fast development of today's digital technology and embedded technology, China's information industry has developed strong enough to become China's primary industry. The application of information technology in education has become imperative. We look forward to solve the problem of student's overweight schoolbag and other educational problems and change the fact that student's learning environment is limited in the classroom by the combination of information technology and education reform. In recent years, the development of electronic schoolbag has been widely concerned. Electronic schoolbag is a new product of electronic education, it is a new attempt to promote the development of education. It is a product of the combination of school teaching contents, methods and computer technology and network technology. In general, it is a new way to promote the development of digital education.

This paper compares the implementation details of the basic functions of different domestic mainstream brand electronic schoolbag, and comments on some characteristic functions of different electronic schoolbag. After the discussion on the implementation details of electronic schoolbag, the paper summarizes some scholar's design scheme of the architecture model of electronic schoolbag. At the end of this article, the paper introduces the development trend of electronic schoolbag.

\section{Comparison of the Basic Function}

Through the analysis and generalization of the overall function of several domestic mainstream brands electronic schoolbag, I found the indispensable main functions of electronic schoolbag, they are: online class function, online test function, ask and answer function, performance calculation function, online homework function, useful materials database function, electronic dictionary function, point and read machine function, multimedia textbook reader function, monitoring function, materials update function. "Fig. 1" lists some basic functions that some electronic schoolbags have or do not have( $\mathrm{Y}$ for have and $\mathrm{N}$ for not have). 


\begin{tabular}{|c|c|c|c|c|c|c|}
\hline & Hunware & LEen & $\begin{array}{l}\text { Lenene } \\
\text { Lex } 53\end{array}$ & Vunjlon & $\begin{array}{l}\text { Wulve } \\
\text { susherg }\end{array}$ & Numun \\
\hline Online das & $\bar{Y}$ & $\bar{Y}$ & $Y$ & $Y$ & $\mathrm{~F}$ & $Y$ \\
\hline Onlive tot & $\mathrm{Y}$ & $\mathrm{Y}$ & $Y$ & $Y$ & $\mathrm{~N}$ & $Y$ \\
\hline Ath and arever & $Y$ & $\mathrm{Y}$ & $Y$ & $\mathrm{Y}$ & $\mathrm{M}$ & $\mathbf{M}$ \\
\hline $\begin{array}{l}\text { Perfomince } \\
\text { cakulution }\end{array}$ & $Y$ & $\mathbf{Y}$ & $\mathbf{M}$ & $\mathrm{M}$ & N & $Y$ \\
\hline Onlife honmorks & $\mathrm{H}$ & $\bar{I}$ & If & $Y$ & $\mathbb{H}$ & 18 \\
\hline $\begin{array}{l}\text { Uteful mukeringt } \\
\text { duthere }\end{array}$ & $Y$ & $\bar{Y}$ & $\bar{Y}$ & $Y$ & $\bar{Y}$ & $\mathbf{M}$ \\
\hline $\begin{array}{l}\text { Evotronil } \\
\text { Aitionary }\end{array}$ & $Y$ & $\mathbf{H}$ & $\mathrm{Y}$ & $\mathrm{M}$ & $Y$ & $Y$ \\
\hline $\begin{array}{l}\text { Poind and mad } \\
\text { mochine }\end{array}$ & $\mathbb{N}$ & $M$ & M & $\mathbf{M}$ & $Y$ & $Y$ \\
\hline 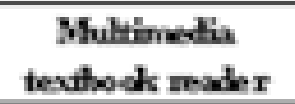 & $Y$ & $Y$ & $Y$ & $\mathrm{~N}$ & $\mathrm{M}$ & $Y$ \\
\hline nonitor & $\mathrm{I}$ & $\mathbf{Y}$ & in & $Y$ & $\mathbf{M}$ & $M$ \\
\hline Muterials wolate & $\mathbb{N}$ & M & $\mathbf{1}$ & $\mathrm{H}$ & $\mathrm{I}$ & $\mathrm{M}$ \\
\hline
\end{tabular}

Fig.1. Comparison of the basic function

\section{Comparison of the Realization Details of Online Class Function}

"Fig. 2" lists some sub-functions that some electronic schoolbag's online class function includes or does not include(Y for include and $\mathrm{N}$ for not include).

The description of sub-functions in "Fig. 2" as follows:

1. Synchronous teaching function: teachers begin his class and teach the students, the students search the class id and log on the class and then participate in conventional classroom activities, such as note-taking, doing exercises in class and communicating with teachers and other students, it includes the following three components:

a. Synchronous flip component: it is a function for teachers, teachers turn the pages of a book through this function, so as to realize the function of synchronous teaching.

b. Electronic notebook component: it is a function for students, students record the important point of the class by using the function.

c. Classroom exercises component: it is a function both for teachers and students, its specific implementation strategies as follows: first teacher send exercises to students, and then students receive and do the exercises, finally they send their answers to the teacher, and the system calculates the correct rate of their answers and other statistical information. In the end, the teacher adjusts their teaching activities according to this information.

2. Self-study function: students use the extracurricular learning materials that the electronic schoolbag provided for their self-study.

3. Interactive communication platform: students ask questions to their teachers and then the teachers answer the questions for their students online through this platform.

4. Textbook click and read function: it can read the textbook of Chinese, English and other liberal and art subjects, it is used for cultivating students' sense of language. 


\begin{tabular}{|c|c|c|c|c|c|}
\hline & 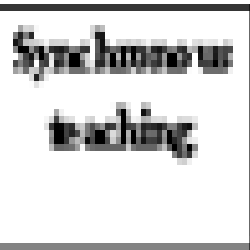 & silfoly & $\begin{array}{l}\text { Word } \\
\text { nound }\end{array}$ & $\begin{array}{c}\text { Intruste } \\
\text { onumaticution }\end{array}$ & $\begin{array}{c}\text { Teat } \\
\text { frinterand } \\
\text { nedrs }\end{array}$ \\
\hline Huxiang & Y & $Y$ & $\mathrm{Y}$ & $\mathbb{N}$ & $\mathrm{N}$ \\
\hline 盀晋 & $\mathrm{N}$ & $Y$ & $\mathrm{Y}$ & $\mathrm{N}$ & $\mathrm{N}$ \\
\hline Lenwo ins & $\mathrm{N}$ & $\mathbb{N}$ & $Y$ & N & $\mathrm{N}$ \\
\hline yingdans & $Y$ & $\mathrm{~N}$ & $\mathbb{N}$ & $\bar{Y}$ & $\mathrm{~N}$ \\
\hline wulwnuther: & $\mathbb{N}$ & $\mathbb{N}$ & $Y$ & $\mathbb{N}$ & $\mathrm{Y}$ \\
\hline Nomeni & $Y$ & N & $\mathrm{Y}$ & $\mathbf{N}$ & N \\
\hline Bhathene & $y$ & $\mathrm{Y}$ & $\mathrm{N}$ & $\mathrm{N}$ & $\mathrm{N}$ \\
\hline
\end{tabular}

Fig.2. Comparison of the implementation of online class function

\section{Conclusion}

As one of new things in the electronic sector, more and more businessmen begin to occupy the electronic schoolbag market, the reason some businessmen would rather take part in the electronic schoolbag market than persist in doing business in their traditional products market is various. However I think there are two main reasons for it: one is that they must do something to response to the requirements of the education reform. The other is that it is easy to make money in the electronic schoolbag market.

\section{Acknowledgement}

In this paper, the research was sponsored by the Department of Educational Technology of the Capital Normal University.

\section{References}

[1] Mu ZhiJia,“Think calmly of the popularity of the electronic schoolbag,”Information Technology Education in the Schools.J.China,vol.150,pp.6-10,June 2004.

[2] Zhu YiMei, "the effect of the introduction of electronic schoolbags on the class,"The Educational Technique and Equipment.J.China,vol.351,April 2011.

[3] Li HuaLong, "How to use the electronic schoolbag in the classroom," The Information Technology Education.J.China, vol.23,July 2011.

[4] Chen ZhiQiang,"We go to school together with electronic schoolbag," The Information Technology Education .J.China,vol.21,2011.

[5] Yu Ren,"How to design electronic schoolbag gradually,” The Education Technology.J.China,vol.20,2011.

[6] Bao PeiLi, “The design of system of electronic schoolbag based on an interactive model,” The Information Technology Education.J.China,vol.33,2011. 
[7] Chen Bin, "Electronic schoolbag promotes innovation of educational model,"The Computer World.J.China,vol.44,June 2010.

[8] Ma YongJi, "The implementation of innovation of the ways of teaching using electronic schoolbag,” The Modern Education Equipment.J.China,vol.20,2012.

[9] Zhao Dong, "there are six disadvantages which hinder the development of electronic schoolbag,”The Computer World.J.China,vol.82,2010.

[10]Li JianPeng, "The current situation of the use of electronic schoolbag and its impact on education,” The Introduction of the Theories of Software.J.China,vol.93,May 2011.

[11]Tang HaiRong, "The advantages and drawbacks of electronic schoolbag coming into classroom,” The Modern Education Equipment.J.China,vol.30,2012.

[12]Wu YongHe,Zhu ZhiTing, “The study on the framework of the standards of electronic schoolbag,” The Information Technology Education.J.China,vol.52,2011.

[13]Zhang LiMing,Fu ChunYan,“The design and implementation of the hardware platform of electronic schoolbag,” The Knowledge of Computer Technology.J.China,vol.68,June 2011.

[14]Zhang LiMing,"The study of the use of electronic schoolbag in education,” The Information of Science Technology.J.Heilongjiang.China,vol.54,2012. 